\title{
Blind spots in agri-environmental governance: some reflections and suggestions from Switzerland
}

\author{
Jérémie Forney ${ }^{1}$ (D) \\ Received: 5 February 2016 / Accepted: 29 February 2016 / Published online: 26 April 2016 \\ (C) INRA and Springer-Verlag France 2016
}

\begin{abstract}
Attempts of making our food systems more sustainable have (partly) failed. Food production still contributes significantly to biodiversity losses, global warming and depletion of natural resources. Based on the postulation that this failure in the governance of environmental issues in agri-food systems relates notably to social and cultural aspects, this paper explores the literature in the social sciences looking for explanations. A first statement is that research around agrienvironmental governance (AEG) issues remains globally split into two subgroups, one focusing on public policies and the other on the civil society or market aspects of environmental certification, with very little exchange or transversal analysis between the two. Drawing on the literature and on longterm fieldwork and research in Switzerland, I identify three dimensions of AEG that open new paths towards more sustainable food systems: an encompassing approach of the food system; the encouragement of collective knowledge creation and the promotion of autonomy. Joining other emerging scholarships, this paper calls for developments in the research on AEG that produce encompassing theoretical frameworks, which transcends pre-existing categories in order to allow new conceptualisation of governance practices in complex or hybrid systems. The integration of the food, knowledge and autonomy dimensions should help in creating innovative and transformative governance instruments.
\end{abstract}

Jérémie Forney

jeremie.forney@unine.ch

1 Anthropology Institute, University of Neuchâtel, Neuchâtel, Switzerland
Keywords Environmental governance · Food system · Autonomy $\cdot$ Knowledge $\cdot$ Social transformation

JEL Classification Q18 · Q50 · Z13

\section{Introduction}

Despite a notable evolution in national policies towards environmentally friendly agricultural models and the burgeoning development of environmental labelling in the food chain, the consensus view is that improvements in the sustainability of food systems have been largely insufficient to meet deeper goals. Agriculture still contributes to losses in biodiversity (e.g. Billeter et al. 2008), to the depletion of natural resources (e.g. on water issues, OECD 2012) and to global warming (e.g. Vermeulen et al. 2012) in a dramatic way. While some relate this partial failure to a lack of technical knowledge on sustainable ways of farming, calling for a new techno-fix and a new green growth, agri-food studies set out to address these challenges in two diverging ways: the first focuses on agrienvironmental policies, with specific attention given to farmers' participation; the second looks at the transformation of food networks and their potential evolution towards more sustainable outcomes. ${ }^{1}$ This divide has already been identified by several scholars calling for a reconnection of the

\footnotetext{
${ }^{1}$ While I choose to focus here on the literature linking agriculture and food networks (agri-food studies), I want to acknowledge the existence and the value of other social sciences fields addressing issues related to food. For example, the anthropology of food tends to focus more specifically on the cultural dimension of food (e.g. Mintz and Du Bois 2002). Furthermore, a wide range of scholarship has also developed around food consumption, often in relation to health issues (e.g. Germov and Williams 2008; Ward et al. 2010).
} 
agriculture and food paradigms (e.g. Hinrichs 2010; Lamine 2015; Lang 2009; McMichael 2000).

This paper in a joinder to this call for reconnection, based on the statement that these two fields of research (agricultural policies and alternative food networks), too often, have developed separately while addressing similar issues. More specifically, it focuses on the issue of environment in the governance of agri-food systems in the so-called global North. Agrienvironmental governance (AEG) works here as an encompassing concept to understand how environmental issues are addressed within the food system by a set of diverse actors of the public and/or private sectors. To do so, I draw on a large set of scholarships on food systems and environment, as well as on a long-term ethnographic work on the adaptation of the Swiss family farming to the recent dramatic political and economic changes. Rather than presenting precise results of my research, I use the Swiss case to illustrate shortly broader lines of reflections on the integration of environmental objectives in the governance of agricultural activities.

A first review of the literature details how scholars have tried to understand farmers' resistance to the ecologisation of agricultural policies. The most promising contributions, while applying diverse approaches, converge around the issue of knowledge in its collective, practical and social dimensions. The recent development of payment based schemes, such as payments for environmental services (PES), indicates the expansion of new market logics within AEG. This trend has been identified for many years by scholars working on food standards in the private or semiprivate sector. Looking for new paths for AEG requires then to review also the often critical literature on this trend, which constitute a major change in the organisation of agri-food networks around the world. Finally, I turn to an emerging body of research exploring new "reflexive" models of governance.

This paper identifies three weaknesses in the current AEG panoply in Switzerland, as well as in a more global context: an enduring disconnection between the mains steps in the food production; the lack of new knowledge creation among the actors involved in the reality of agri-environmental practices; and the lack of autonomy in a very controlled food system. Building on these three gaps, I argue that an encompassing approach of the food system; the encouragement of collective knowledge creation and the promotion of autonomy open new paths towards a more sustainable governance of agri-environmental issues.

\section{Agri-environmental governance: a bifurcated field of research}

\section{Agri-environmental policies: resistance and knowledge creation}

The most obvious way of governing agri-food systems is through state policies. The reorientation of agricultural policies towards more environmental friendly practices is an important element in the development of sustainable food systems. Many scholars have described the post-productivist and 'green' turn, above all in the European context (e.g. Deverre and de Sainte-Marie 2008; Evans et al. 2002; Mather et al. 2006; Wilson 2001). One of the core concepts, both at the political and analytical levels, has been the 'multifunctionality' of agriculture (Bazin 2003; Potter and Burney 2002; Wilson 2007). This concept legitimises state financial support to farmers by highlighting the public, nonmarketable services they provide, above all environmental conservation.

This evolution of European-style public policy implied a significant redefinition of the mission given by society to farmers and consequently has had a major impact on their professional identity. Taking farmers as the traditional focus of rural and agricultural studies, scholars have highlighted the tensions between post-productivist policies and farmers' identities (e.g. Burton et al. 2008; Burton and Wilson 2006; Droz 2001; Droz and Forney 2007; Forney 2012; Lemery 2003). Research has shown notably that financial motivators were sometimes useful but not sufficient to promote long-term change in behaviour and attitudes (Schneider et al. 2010; Wilson and Hart 2001). In western industrialised countries, farmers' productivist values, often seen as an obstacle to sustainability, are deeply rooted in their self-definition (Burton and Wilson 2006; de Snoo et al. 2013; Walford 2003). The most useful developments focus on the social, interactive and collective dimensions of this resistance. For instance, scholars have drawn on the Bourdieusian sociology of capitals to identify farmers' definitions of 'good farming', and the social costs of adopting alternative practices that are seen as a negation of the productive role of the 'good farmer' (e.g. Burton 2004; Burton et al. 2008). While the timid mainstreaming of alternative views on agriculture, namely organic farming, may allow for some redefinition of 'good farming' at a broader level (Sutherland 2013), farmers have proved resistant to models in which they are viewed merely as the 'country's gardeners', as in the Swiss context (Droz 2001; Droz and Miéville-Ott 2001).

Indirectly echoing these analyses, other studies explore how alternative modes of farming have nevertheless been invented or renewed at a local scale, through farmers' participation in new networks of knowledge-sharing (e.g. McGuire et al. 2013; Schneider et al. 2009). Sustainable agriculture is said to be knowledge intensive, and accordingly requires specific forms of knowledge that farmers might not possess (Ingram 2008b; Siebert et al. 2008). This deficit is evident both in relation to scientific understanding of natural processes such as soil health and erosion (Curry and Winter 2000) and in relation to environmental management (Siebert et al. 2008). Therefore, farmer re-skilling and the importance of knowledge acquisition in the implementation of AEG schemes 
becomes a key issue for the success of public policies (Curry and Winter 2000; Ingram 2008a; Juntti and Potter 2002). The evolution of the kind of knowledge farmers are expected to master, implies broader change in the knowledge system in agriculture, notably in the extension activities (e.g. Lemery 2006). Many scholars insist on the importance of a diversity of knowledge and learning processes and the difficulties of translating expert knowledge into the localised forms of know-how (e.g.Bruckmeier and Tovey 2008; Siebert et al. 2008). More particularly, the circulation of knowledge in farmers' networks has been studied as an important factor in the diffusion of environmental friendly practices (Compagnone 2014; Compagnone and Hellec 2015). More radically, some authors called for a reorientation of the agricultural sciences by drawing on the local knowledge produced by farmers (e.g. Kloppenburg 1991). As I will discuss it later, most of these contributions tend to adopt a rather narrow and technical understanding of knowledge and they forget its social dimension. Still, they lead to an important preliminary conclusion: while most environmental schemes target individual farmers, the collective dimension is essential in processes of appropriation (or refusal) of environmental objectives, because it facilitates the creation and sharing of knowledge and values. In this sense, the development of collective initiatives such as environmental co-operatives opens up interesting questions about more participative forms of AEG or 'selfgovernance' practices (e.g. Franks and Mc Gloin 2007; Glasbergen 2000). As highlighted by these studies, one of the positive effects of farmers' collaboration over environmental actions is related to scale, as many environmental issues are better addressed at the scale of an entire landscape rather than at the level of individual farms. However, it is also acknowledged that individual concerns about autonomy sometimes prevent farmers from participating in collective environmental schemes (Franks and Emery 2013). More generally, the 'regulatory treadmill' of agri-environmental policies (Horlings and Marsden 2011) has been identified as a key factor in discouraging alternative farming practices, and calls have been made for the design and implementation of more flexible schemes (Emery and Franks 2012; Home et al. 2014).

Payments for ecosystem services (PES) arguably offer a new kind of answer to these issues. These instruments are based on the assumption that deficits in the provision of environmental goods result from a lack of appropriate markets, which they intended to create. Inspired by Coasean economic theory (Van Hecken and Bastiaensen 2010), they apply (quasi-)market logics to environmental management. While labels market the environment through the food it produces, PES are designed to 'sell' environmental practices in their own right. Thus for example, one might ask users of a river promenade to subsidise or 'pay' farmers for activities that help to conserve the river's ecosystem. In this perspective farmers (or land owners) are not seen as potential polluters that should be controlled and governed, but as service providers for external users (Castree 2003). By switching from a polluter-pays to a beneficiary-pays principle (Muradian et al. 2010), PES has the potential to impact citizens' understanding of environmental responsibilities in new ways. At the same time, it participates in the 'commoditisation' of the environment and of nature (Boisvert et al. 2013; Maris 2014), and has been criticised from many corners (e.g. Bakker 2010; Wolf and Bonanno 2014) as part of the on-going debate around the 'neoliberalisation' of nature and of agri-food systems. Focusing specifically on farmers' motivations for engaging in PES, Wynne-Jones (2013) argues that because of their market orientation and related financial incentives, these payments may be better suited to farmers' identities as entrepreneurs. However, her research indicates that farmers tend to prioritise food production and long-term farm preservation over market strategies and short term benefit. In addition to this, a range of other critiques has been directed at PES. For example, Norgaard (2010) doubts that such a tool can integrate the complexity of present environmental challenges. Van Hecken and Bastiaesnen (2010) point to the risk that PES reproduce and deepen social injustice and inequalities, as poor communities would face difficulties in paying for ecosystem services that they were previously enjoying for free.

\section{Cross-sectorial approaches: alternative food networks and private standards}

The literature above, while providing useful insights, suffers from its virtually exclusive focus on production, thereby failing to engage with the complexity of the wider food system (Goodman and DuPuis 2002). The same can be said about the policies that are discussed. In answer to this 'lost in production' syndrome, more systemic approaches have been developed, notably through the study of small-scale alternative food systems that have emerged from the civil society (for a review see Goodman et al. 2014; Tregear 2011) such as local food networks or farmers' markets that promote environmentally friendly modes of agriculture (e.g. Bowen and Mutersbaugh 2014; Wittman et al. 2012). These approaches point to the systemic and structural character of the (un-)sustainability of food systems (e.g. Lamine 2012).

At a larger scale, the integration of sustainable farm practices (e.g. organic farming) within conventional food networks has been criticised as a process of 'conventionalisation' that would reduce most of the benefit of such practices (Buck et al. 1997; Guthman 2004). Other authors adopt a more nuanced perspective, exploring the interconnections between alternative and conventional networks (Rosin and Campbell 2009; Sonnino and Marsden 2006). Beyond these debates, food network (or system) approaches help us overcome sectorial limitations by identifying AEG developments in other 
arenas than those of state policy. Interestingly, such approaches have developed in parallel with the awareness of a dramatic globalisation of food networks. Food and agriculture problems are articulated more and more beyond the national level, as illustrated by the global dimension of the food crisis in 2008 (Lang 2010; Rosin et al. 2011). This evolution of food networks has had a crucial impact on governance issues. Nation-state policies appear increasingly limited, while transnational corporations gain growing economic and political power (Clapp and Fuchs 2009), first in the processing industry (Friedmann and McMichael 1989) and more recently in retailing (Burch and Lawrence 2005; Dixon 2007).

The crisis of 2008 also highlighted the growing importance of actors from the finance sector, which has been consistently underestimated. Hedge funds and private equity firms invest massively in agricultural produces (wheat, sugar, corn, soy...), inputs and logistics, as well as in farmland. This evolution had a dramatic impact on the agri-food system at a global scale, as the example of the development of biofuel clearly illustrates (McMichael 2012). As suggested by Burch and Lawrence (2009), the growing importance of financial actors influenced the rules of the whole agri-food system, provoking other corporate actors to develop 'rent-seeking' strategies. This 'financialisation' of agri-food systems has obvious relations with the issue of neoliberalisation (Lawrence and Campbell 2014).

NGOs, certifiers and a variety of non-state organisations complete the complex picture of the actors involved in the governance of 'global value chains' (Gibbon et al. 2008) in the food sector. Consequently, the regulatory space is occupied by a mixture of state and non-state players mobilising a wide diversity of AEG tools (e.g. Gereffi et al. 2005; Gorton et al. 2011).

Private standards and labels have become central tools of governance and are of particular interest for my purpose. Private standards have a long history. They emerged in different context, notably in the 1930s within the French wine industry. However, they expanded largely in response to the food crises of the 1990s, targeting the security of consumers in northern industrialised countries by imposing quality standards on farmers and manufacturers (Fuchs et al. 2011). From the beginning, however, they also engaged in the regulation of environmental and social issues. While a few of these standards emerged from civil society (e.g. Slow Food), most were initiated by supermarkets in attempts to secure their positions in new niche markets (Friedmann and McNair 2008). Through these processes, third-party environmental and social certification initiatives have grown and become identified as key agents in the regulation of food production (Raynolds et al. 2007). The collaboration between big retailers and certifiers has resulted in a plethora of labels within an expanding 'audit culture' (Campbell 2009; Campbell et al. 2012). These practices play a crucial role as 'standards makers' (Bain et al.
2005), both in highly regulated European countries and in more neoliberalised economies where state policies have been "rolled back" through deregulation (e.g. New Zealand and Australia, see Higgins et al. 2008; Rosin 2008).

Scholars have often been quite critical of these new forms of governance, identifying them as a key component of the extension of retailer power, particularly over manufacturers and farmers (Clapp and Fuchs 2009; Hattersley et al. 2013; Richards et al. 2013) with unintended impact of processes of standardisation on people and things (Davey and Richards 2013). The growing legitimacy of the market principles on which such standards are based also allow retailers to dominate the terms of debates on food (Dixon 2007), and to devise, as with other powerful enterprises, their own standards for 'corporate social responsibility' (Crouch 2011).

More generally, some scholars relate these new tools to a neoliberal mode of governance of food and natural resource management (Le Heron 2003) that relies on market logics and consumer choice rather than democratic regulation and state intervention (Guthman 2008; Moberg 2014). According to Guthman (2007), while they express ecological and social values, food labels actually reproduce dominant aspects of the neoliberalisation of environmental governance and nature (Castree 2008a; Heynen and Robbins 2005). Other authors, such as Bacon (Bacon 2010), present a more nuanced picture, showing how labels result in highly contested fields that are subject to an array of constraints and contingencies, and where neoliberalisation is just one force among many. The emphasis on the hybridity and complexity of governance in the socalled neoliberal food regime (Wolf and Bonanno 2014) echoes other research on neoliberalism 'as exception' rather than hegemony (Ong 2006). Similarly, the idea of 'neoliberalisation of nature' has been largely criticised on two other points: for presenting neoliberalisation as a unified trend, and for its narrow definition of 'nature' (Bakker 2010; Castree 2008b). Still others have contested the common idea that neoliberalisation automatically entails a 'roll-back' of the state, as neoliberal governance often implies specific processes of re-regulation (Castree 2008b) producing not less state but rather a new conjuncture of the state and the private sector (Mansfield 2004).

Corporate power in AEG has also been addressed in terms of legitimacy, raising the question of the democratic dimension of private standards as compared to governance tools developed by democratic procedures. The questions of legitimacy extend to the whole process and have consequences at different loci of the value chain (Henson 2011). As an example, scholars have worked on the consequences of European quality standards (GlobalGAP) for southern producers and consumers, questioning the claimed positive outcomes regarding social sustainability (Fuchs et al. 2011; Dolan and Humphrey 2000). In the global South, as well, standards seem to reinforce the structural power of transnational corporation 
over local actors (Scott et al. 2009), resulting in a form of food governance with striking similarities to other forms of imperial governance (Freidberg 2007). The recent development of southern-based quality standards (ChileGAP, KenyaGAP) challenges, however, the North-south dimension of this debate (Tallontire et al. 2011).

To regroup both alternative food systems resulting from action of the civil society and the strategies of big corporate groups might be a surprising choice. However, my point here is to underline the lack of discussion and exchange in the literature between two sets of scholarships. The first deals with agri-environmental policies and too often forget to look at the interaction with economic practices. The second addresses changes at the level of agri-food networks, where the boarders between civil society and private economy are often blurred and overlapping, but do not focus on the mechanism of state interventions. The result is a generally bifurcated representation of the governance of agri-food systems.

\section{Un(-sufficiently)explored paths towards environmental sustainability}

As I will develop later, this review of the literature allows me to identify paths to be explored. First, as described above, research on AEG remains globally split into subgroups, some focusing on public policies, others on the civil society or market aspects of environmental certification, with very little exchange or transversal analysis between them. As the multiplication and diversification of AEG instruments makes clear, traditional oppositions such as public (state) versus private (market) hinder our understanding of what has become a hybrid and polycentric governance system that combines markets and hierarchies, national regulation and local implementation, voluntary certification and globalised standardisation (Lockie and Higgins 2007; Ménard 2004; Ostrom 2010). New insights have been generated around the governance of value chains, but most of the research reproduces the preexisting delineation between private and public, even while claiming that public and private dimensions are mixing. In our view, more recent scholarships on 'eco-economies' (Kitchen and Marsden 2011; Marsden 2010) and 'biological economies', undertaken in a cross-sectorial "assemblage" perspective (Campbell et al. 2009; Lewis et al. 2013), offer new insights that transcend these limitations and strengthen our ability to observe and analyse emerging trends. In particular, these developments are helpful in comprehending new local-based food governance practices regrouping a diversity of actors and participants, such as the concept of 'urban foodscapes' (Morgan and Sonnino 2010) or an emerging 'integrated and territorial mode of food governance' that reunifies the three levels of government, civil society and market (Wiskerke 2009). Stressing that global pressures are affecting the "stable regulatory period of post-productionism and retailer-led, private-interest governance", Marsden calls for place-based strategies and reflexive governance practices adapted to the specific needs of local communities (Marsden 2013). Such reflexive governance is characterised by the inclusion and participation of a wide range of actors and important processes of social learning and social innovation (McKee et al. 2014; Sonnino et al. 2014).

Second, while issues of knowledge creation and 'good farming' relate both to the cultural dimension of farming, they have generally been studied separately. Very few connections have been explicitly made between the creation of new knowledge and the transformation of collective farmer identities. Bell (2004) insists on the relationship between new knowledge and new values in the emergence of individual farmer subjectivities, and Burton and Paragahawewa's (2011) use of the concept of cultural capital has similar potential. However, little is known about how and under which conditions new knowledge and practices receive collective symbolic valuation and start to change wider definitions of good farming. This gap is even more obvious among other actors (non-farmers) along the food chain. Yet this social process is arguably central to the emergence of agrienvironmentally friendly farming systems and food networks. The interconnections between knowledge creation and collective identity require closer attention, particularly in relation to AEG issues, as proposed in this project.

Third, while farmers' resistance to agri-environmental policies has been analysed, social scientists have thus far made few actual recommendations for improving the situation. Burton and Schwarz's (2013) or de Sainte-Marie's (2014) works on the potential of payment by results is an exception, along with the research of McGuire et al. (2013) on the impact of performance-based environmental management on farmers' identities through feedback loop effects. There is a serious need for further applied research on the design of AEG instruments capable of fostering more sustainable agricultural systems. I argue that a theory of farmer autonomy as a tool for identification and adaptation (Stock and Forney 2014) both opens up understandings of potential farmer actions and can fruitfully be extended to other groups of actors along the food chain, as an example in addressing the complex question of consumers' choices, or in analysing the side-effects of diverse dependencies and interdependencies within agri-food networks.

\section{AEG in Switzerland}

The insights on the Swiss agri-food system that I use in this paper result from a long-term ethnographical work in the Swiss agricultural sector. I draw from a several research projects developing different aspects of the adaptation of the farming population to the political and economic changes that 
started in the 1990s. Altogether, the data that have inspired the ideas developed here have been collected between 2002 and 2014, in several parts of French-speaking Switzerland (mainly Canton of Vaud, Fribourg and Neuchâtel). They include a large number of semi-structured interviews with farmers and other actors of the industry (138), direct or participant observations, and document analyses.

Switzerland presents interesting particularities for the purpose of a reflexion on AEG. Notably, the combination of strong agri-environmental policy and numerous private and market-oriented environmental labels have put to the forefront of everyday and public debates the complex relation between food and environment. The diversity of state-based instruments includes both federal policy and regional, localised actions. Swiss agri-environmental regulation has been intensely developed from the 1990s onward with a radical reorientation towards multifunctionality (Droz 2001; Wilson 2007). Farmers' compliance with agri-environmental regulations is a condition for accessing state support, which has become essential for farm survival because of decreasing prices for farm products in a context of progressive liberalisation of agricultural production and markets. The federal state's expenses for agriculture equals something like 3.5 billion Swiss francs (roughly the same in euros) a year. This is quite a lot for a country of 7 million of inhabitants. State money represent a significant part of the farm income (around $70 \%$ of the total income), with an average around 64,000 Swiss francs a year per farm (FOAG 2015). Consequently, most of the attention and debates related to the integration of environmental consideration in agriculture revolve around the official agricultural policy.

However, beside this strong and overshadowing set of public based instruments, there is a profusion of retailer-based instruments of AEG as well, above all certified labels. The Swiss food retailing sector is clearly dominated by two mains actors: Migros and Coop. These two companies share a de facto duopoly, as well as many similarities, in particular their structure and identity as large scale co-operatives (Réviron and Chappuis 2005). The competition for market share and the importance of securing safe and reliable provisioning has led them to develop strategies for differentiation. While Migros attempts to demarcate itself through regional products in accordance with its regional structures, Coop has positioned itself as a promoter of environmentally sustainable food production for many years. In 1993, Coop launched its 'Coop Naturaplan' brand, taking a leading role in the commercialisation of organic products in supermarkets, in collaboration with Bio Suisse (the federation of Swiss organic farmers). Arguably, this alliance participated in the 'conventionalisation' of organic agriculture. Recently arrived competitors (the German hard discounters Aldi and Lidl) have developed communication on the environmental aspects of food as well. Environmental sustainability is now, along with local provenance and, of course, low prices, part of the dominant language of food marketing in Switzerland. ${ }^{2}$

Paralleling these large-scale sets of governance practices, many small-scale initiatives have emerged within the civil society. They relate generally to processes of re-localisation of the food procurement. Box schemes, organic or conventional, have multiplied in all the country following a few precursors that have been active since the 1970s in big towns, notably Geneva. More recently urban food strategies have developed in several places, creating new space of reflection and discussion about the relations between the town and the provision of food (Salomon Cavin 2013; Wallimann 2015). More generally, process of food re-localisation have developed throughout all the Swiss food systems, with the development of several types of strategies ranging from institutionalised certifications of origin (Boisseaux and Leresche 2002) to more unformal revaluation of the product's provenance (Forney and Häberli 2016).

\section{Food, knowledge and autonomy}

My claim here is that reconnecting research to the following three aspects of food governance opens new paths towards more sustainable governance practices: taking food as an encompassing analytic and policy framework; encouraging the collective construction of new agri-environmental knowledge and cultures; and recognising farmer autonomy as a tool for adaptation. If systemic perspectives on food and a focus on knowledge have already been largely explored, my point is that possible paths were forgotten, notably in connecting the three dimensions of food, knowledge and autonomy in the emergence of new agricultural and food cultures/identities.

Such an approach requires a particular approach to AEG, grounded in the description and analysis of its instrumentation (Lascoumes and Le Galès 2005, 2007). Governance 'instruments' are organised sets of rules, good practices, metrologies and procedures, articulated and developed in order to exercise social control over a targeted population and to influence practices. An instrument develops within a network of actors, creating new ties and reformulating older ones, enacting specific logics and norms and referring to specific forms of authority (Olivier de Sardan 2010). The application of a governance instrument results in varying outcomes as actors make use of them in new and reinvented ways. Beyond instruments and their design and materiality, localised practices, specific networks and practical norms emerge in a process of interaction, translation and reinterpretation that we can call "everyday

\footnotetext{
$\overline{2}$ This is a very condensed and general presentation of the Swiss context, as my objective is only to give to the reader a broad idea of AEG in Switzerland. For further descriptions of the Swiss agricultural policy, see Mann (2003)
} 
governance" (Agrawal and Gibson 1999 ; Blundo 2002) or AEG practices. Consequently, this papers advocates a "meso point of view" (Blundo and Le Meur 2009) on governance, which would look at how AEG is produced through repeated interaction between diverse actors constituting an AEG network. Among the key actors of such networks, some are human, from policy makers to private certifiers, from supermarket boards to farmers' associations. Others, however, are not: indeed, legal documents, metrological tools, soil, animals and many non-human actors also play a central role and are not passive recipients of human action.

In the following, I illustrate some of the issues related to each of these three dimensions, using short examples from the Swiss context, in order to open on a few conceptual developments.

\section{Food as framing and symbol}

Almost every Swiss farmer I met during more than 10 years of research told something that can be summarised as: "Environment, it's Ok, but my job is food production." What is striking in this assertion is the structural opposition between two functions: environment and food production. This opposition is translated in identity terms, assimilating food production to what a farmer really is and, consequently, environment, to what he is not, at least not essentially. The study by Home et al. (2014) confirms this oppositional conception, which, obviously, is not a good starting point to get farmers buying in more environmentally friendly farming practices. This opposition reflects as well in the design of the Swiss Agricultural Policy. Direct payments are attributed to farmers for specific practices promoting biodiversity or animal welfare, independently from the food production resulting (or not) from the farming activity. More generally, beside the general aim of the national food security or a fuzzy productivist and quantitative narrative of 'feeding the world' there is no real integration of a broader food dimension into the agricultural policy. As an example, and as others have observed for the CAP in the UE (Birt 2007; Lang 2009; Schäfer Elinder et al. 2003), despite the dramatic role that nutrition plays in public health issues today, the Swiss federal agricultural and health policies remain completely separated. As underlined by Bricas et al. (2013) for the French context, there is a real need of re-addressing and reformulating the relations between agriculture and food.

This separation of agricultural policies and broader foodrelated issues manifests as well in the framing of agrienvironmental governance as an agricultural concern exclusively. As an illustration, a comparative review of the development of organic policy networks in European countries, including Switzerland, (Moschitz and Stolze 2009) does not mention at all the obviously important role played by retailers in the development of organic markets. Here we find again the splitting of the research on AEG between public policy and private governance, which illustrates a broader societal separation between agriculture and food, as recently pointed by Lamine (2015).

Systemic approaches to agri-food issues have long been advocated as a way to counter this compartment thinking and reunify agriculture, food and the environment (e.g. Hinrichs 2010; Lamine 2015). Indeed, there is more than 'just' systemic thinking in a food approach. Kloppenburg et al. (1996: 41) refer emphatically to the "centrality of food in our lives and its capacity to connect us materially and spiritually to each other and to the earth". More materialistically, adopting a 'food framework' requires a broad understanding of AEG as an 'assemblage' (Le Heron et al. 2013). Food as a guiding concept reassembles activities and networks of human and non-human actors that have too often been separated, specifically throughout agricultural production, environmental conservation and sustainable consumption. The food framework allows us to reconsider current challenges facing agriculture, and to make connections with broader issues such as health, resources management and demography (e.g. Goodman and DuPuis 2002; Levkoe 2011; Marsden 2000). The impressive development of organic food offers a good example of the power of new connections between specific agricultural practices (e.g. chemical free) and new criteria for food quality, associated with both health and sustainability. This assemblage is, arguably, a key element - though not the only one-in the success of the organic food chain. Furthermore, reconnecting AEG with the food dimension of agricultural practices is also necessary at the symbolic level. Food is an essential element of human life and this makes it a strong vector for values and identities, both in consumption and production. As formulated by McMichael (2000), food "embodies the links between nature, human survival and health, culture and livelihood". Acknowledging this symbolic force is crucial in providing actors along the food chain with the conceptual tools to collectively recreate meaning and consistency in new and more sustainable production and consumption habits.

\section{Building on collective knowledge}

This focus on new meaning is related to a second dimension in AEG: the creation of collective knowledge and learning processes as key elements for socio-environmental change. In Switzerland, existing AEG tools generally relate to a list of very precise top-down requirements that the farmers have to follow in order to get some state money or a private based label, e.g. grass that cannot be mowed before the 1st of July, limitations of nutrient and chemicals. For farmers, there are no objectives to reach, no challenge despite the one of coping with the ever evolving set of rules and the increasing volume of paperwork. Such AEG instruments might produce new skills among farmers, but mostly in administration and 
management work. Farmers are not expected to develop new environmental knowledge or skills. As a consequence, the Swiss farmers I interviewed, when talking about environmental schemes, often mentioned their unease to be paid for doing 'nothing'. Environment friendly practices are seen as 'doing less'. Similarly, the criteria for being integrated in retailers-led environmental or animal welfare labels are defined in a very top-down way, e.g. square meters per capita in the stable, numbers of trees in the walking area... Again, farmers just have to comply with a ticking-box style list. Nobody seems to care if they understand and agree with the requirements, or if some specificity of their particular situation influence the results of the scheme in an unexpected way. There is some sort of alienation in this process and this statement fits very well with Burton et al. (2008) interpretation of farmers' resistance to environmental schemes in terms of social and cultural capitals: no knowledge, no sense of work, no pride, no transformation.

In the literature, issues of knowledge are generally understood in cognitive terms: the ability to apply new techniques and to understand the complexity of ecological issues in their interaction with farming practices. While technical knowledge and know-how play a central role in the practice of sustainable farming, Carolan (2006) points to the deeper implications of processes of knowledge creation and mastery and their impact on people's evaluation of the benefit of farming practices. Knowledge influences how we 'see' the world and developing sustainable agriculture is a matter of facilitating new ways not only of knowing but also of seeing. Thus, knowledge has to be understood in a broader sociological sense. Following the works of Foucault and Bourdieu, knowledge relates to power and hierarchies on the one hand, and, more modestly, to selfesteem and recognition on the other, the two aspects being interconnected. In other words and following Foucault's distinction between 'savoir' and 'connaissance' (Foucault 1994), the creation of collective forms of knowledge is more than individual 'know-how'. Collective knowledge gives birth to new socio-cultural resources. In Bourdieusian terms, it produces cultural, symbolic and social capital, which contributes to re-define social positions and open up new ways to prove one's value in a given social field (see e.g. Bourdieu 1979). In the farming context, this means that new practices and knowledge result in transformation of the definition of 'good farming'. More fundamentally, new knowledge allows for reinterpreting one's situation and finding new possibilities for sense-making. This is of particular importance for the Swiss farmers, who express a growing sense of disconnection between their aspirations and the evolution of the political and economic context they find themselves in (Forney 2007, 2012). Bell's (2004) work on "practical farming" in Iowa provides an excellent example of how the development of new farming practices articulates with new networks of knowledge and value sharing, allowing individuals to regain control over what they do and why they do it. In short, knowledge building is associated with empowerment and autonomy. These considerations on the importance of collective knowledge parallel other approaches in development studies, such as 'social learning' (e.g. Davidson-Hunt 2006; Rist et al. 2007). For instance, Schneider et al. (2009), apply a social learning perspective in their study of a farmer to farmer learning process in agricultural soil management in Switzerland, which allows them to address the "transformation of the values, norms, rules and power relationships that govern the use of agricultural soils" (Schneider et al. 2009: 476). Their work illustrates nicely the potential of non-hierarchical collective process of knowledge-sharing and building.

Collective knowledge creation is not limited to farmers, however, and the same attention to knowledge should be given to other groups of actors (horizontally, e.g. among retailers, among manufacturers) and across networks (vertically), between actors with different functions and activities along the food chain. This attention would operationalise a definition of governance practices as dynamic phenomena that include learning processes (Henson 2011). Thus, what I call 'collective knowledge' presents strong similarities with 'second-order learning' processes in reflexive governance practices, described by Marsden (2013: 131) in relation to "awareness of and change to interpretive frameworks".

\section{Autonomy}

Independence and autonomy are key factors in professional identification and in decision-making for farmers (e.g. Niska et al. 2012; Stock and Forney 2014). Discussions on farmers' autonomy has generally been oriented towards a criticism of the industrialisation, and more recently financialisation, of agriculture, resulting in their subsumption and domination (e.g. Mooney 1988; van der Ploeg 2008). Current challenges to farmers' autonomy are complex and multiples. In Switzerland, the association of market deregulation and multifunctional agricultural policies result in a double pressure. The first is classically related to processes of industrial integration. As an example, the removal of the milk quota system clearly disempowered dairy farmers in their relation to the industry (Forney and Häberli 2016). The second ensue from the public and private environmental regulations that increasingly constrain farmers' room of manoeuvre. Furthermore, the obvious contradiction between self-representations as autonomous and independent farmers on the one hand and the clear dependency to state subsidies are clearly stated by every interviewed farmer and regularly pointed out by farmers' unions' representatives in professional newspapers. The loss of confidence resulting from this situation produce clear psychological suffering in the farming population (Droz et al. 2014), but do not restrain farmers' search for autonomy. 
Farmers value their independence and autonomy even in very constrained situations caused by political and economic relations of dependency (Stock and Forney 2014). Thus, 'autonomy' must be conceived not only as a moral value but as a positive 'project of self-constitution' (Böhm et al. 2010: 20) and, as such, is a valuable 'social tool' for adaptation. Farmers refer to autonomy to create a sense of identity ("this is what I am"); to navigate constraints ("this is what I can do"); and to buffer change in the playing field ("this is how I can react") (Stock and Forney 2014). Autonomy as part of a farming self involves the formation and evolution of an identity as a farmer in changing social, economic and ecological contexts. This preliminary theory of autonomy helps us understand the role autonomy plays in actors' enrolment in AEG practices and the invention of new environmental subjectivities. In networks where interdependencies are strong, as in most food networks, individuals are limited and constrained in their ability to implement changes by themselves. However autonomy can be understood also at a collective level, as a collective effort rather than individualistic freedom (Stock et al. 2014), in this sense, autonomy refers to the ability to engage individually and collectively for common goals, as a way of gaining some room for manoeuvre at a collective level and as a way to create paths for action that impact the system. The persistence of cooperative structures in increasingly liberal contexts offers a good illustration of the importance of collective strategies among farmers, for example in Switzerland (Forney and Häberli 2016). All these developments indicate that leaving room for autonomy would be a key element for transformative AEG practices.

\section{Conclusion}

This paper reviewed a large, but never exhaustive, set of writings related to the governance of agri-food systems and environment. I used short ethnographical insights from the Swiss context as illustrations. This process allowed me to identify three socio-cultural dimensions of AEG that, I argue, constitute together a promising path to follow, with the aim of developing new approaches that looks transversally at AEG and contribute to produce more sustainable food futures: reconnection with (and through) food production, collective creation and recognition of knowledge, and emerging possibilities for farmer autonomy. I argue that at the most general level, these three dimensions can serve both as a guide for assessing existing AEG instruments in different national contexts as well as at the transnational level, and as concepts that can help us rethink current policies and propose new orientations for private and public regulations and policy-making.

To follow this path equals to be looking at the transformative potential of AEG instruments. What are the changes they (could) provoke in the concrete everyday life of the food system actors? How does this modification of the actors' experience induce a transformation of the 'spirit of food'-I am expanding here the idea of the emergence of a "new spirit of farming" offered by Rosin (2008) - with a progressive integration of environmental values and practices? This paper calls for more research on these essential questions that have too often been overshadowed by an obsessive attention given to direct and quantitative outputs of AEG in terms of economic or ecological efficiency. The difficulties that classical approaches have met in order to produce effective answers to the many food challenges facing our globalised societies (e.g. Lang 2010; Marsden 2012; Rosin et al. 2011) confirms the need for developing renewed orientations in the research on the governance of the agri-food system.

To do so, we should start with looking carefully at what place and role take - more or less willingly - diverse actors (human and non-human) in the food system and its evolutions. This includes ourselves, as academics and researchers. As an open conclusion, I suggest that a self-reflexive posture plays a central role in the development of an 'enactive research' in rural and food issues, called on by Philip Lowe (2010). Looking for new solutions in AEG would mean then to rethink our research practices at every level: methods, theories and epistemologies (Forney 2016). A few research groups have already started to work in such promising directions. I have already mentioned the research done on 'reflexive governance' (Marsden 2013) and 'biological economies' (Campbell et al. 2009; Le Heron et al. 2016; Lewis et al. 2013). I should probably add others, for instance the work of Michael Carolan on embodied food politics and coexperimentation (Carolan 2011, 2013) and the thought provoking collective developments around food utopias (Stock et al. 2015). These examples of explorative and emerging scholarships give illuminating insights on what could be a renovated agri-food research that looks at contributing to the development of better food system, in a particular and original way that is neither activism, nor distant and cold expertise.

Acknowledgments This paper has been written in relation to the research project "New directions in agri-environmental governance: Reassembling food, knowledge and autonomy" funded by the Swiss National Science Foundation (subsidy number PP00P1_157414). I would like to thank Ellen Hertz and Hugh Campbell for their invaluable advises and constructive critics on a former version of the paper, as well as the two anonymous reviewers for their useful comments.

\section{References}

Agrawal A, Gibson CC (1999) Enchantment and disenchantment: the role of community in natural resource conservation. World Dev 27:629-649

Bacon CM (2010) Who decides what is fair in fair trade? The agrienvironmental governance of standards, access, and price. $\mathrm{J}$ Peasant Stud 37:111-147 
Bain C, Deaton B, Busch L (2005) Reshaping the agri-food system: the role of standards, standard-makers and third-party certifiers. In: Higgins V, Lawrence G (eds) Agricultural governance: globalization and the new politics of regulation. Routledge, Abingdon, pp 71-83

Bakker K (2010) The limits of 'neoliberal natures': debating green neoliberalism. Prog Hum Geogr 34:715-735

Bazin G (2003) La PAC contre la multifonctionnalité? Economie Rurale 273-274:236-242

Bell MM (2004) Farming for us all. Practical agriculture and the cultivation of sustainability. The Pennsylvania State University Press, University Park, p 312

Billeter R, Liira J, Bailey D, Bugter R, Arens P, Augenstein I, Aviron S, Baudry J, Bukacek R, Burel F, Cerny M, De Blust G, De Cock R, Diekötter T, Dietz H, Dirksen J, Dormann C, Durka W, Frenzel M, Hamersky R, Hendrickx F, Herzog F, Klotz S, Koolstra B, Lausch A, Le Coeur D, Maelfait JP, Opdam P, Roubalova M, Schermann A, Schermann N, Schmidt T, Schweiger O, Smulders MJM, Speelmans M, Simova P, Verboom J, Van Wingerden WKRE, Zobel M, Edwards PJ (2008) Indicators for biodiversity in agricultural landscapes: a pan-European study. J Appl Ecol 45:141-150

Birt C (2007) A CAP on health? The impact of the EU common agricultural policy on public health. Faculty of Public Health, London, UK, p 28

Blundo G (2002) Editorial. La gouvernance, entre technique de gouvernement et outil d'exploration empirique. Bulletin de l'APAD https://apad.revues.org/129 23-24, 2-10. Accessed 03 July 2015

Blundo G, Le Meur P-Y (2009) Introduction: an anthropology of everyday governance collective service delivery and subject-making. In: Blundo G, Le Meur P-Y (eds) The governance of daily life in Africa: ethnographic explorations of public and collectives services. Brill, Leiden, pp 1-37

Böhm S, Dinerstein AC, Spicer A (2010) (Im)possibilities of autonomy: social movements in and beyond capital, the state and development. Soc Mov Stud 9:17-32

Boisseaux S, Leresche J-P (2002) Dynamiques régionales et globalisation: le cas de la politique des AOC-IGP en Suisse. Swiss Political Science Review 8:35-60

Boisvert V, Méral P, Froger G (2013) Market-based instruments for ecosystem services: institutional innovation or renovation? Soc Nat Resour 26:1122-1136

Bourdieu P (1979) La distinction. Critique sociale du jugement. Ed. de Minuit, Paris, p 672

Bowen S, Mutersbaugh T (2014) Local or localized? Exploring the contributions of Franco-Mediterranean agrifood theory to alternative food research. Agriculture and Human Values 31:211-213

Bricas N, Lamine C, Casabianca F (2013) Agricultures et alimentations: des relations à repenser? Nat Sci Soc 21:66-70

Bruckmeier K, Tovey H (2008) Knowledge in sustainable rural development: from forms of knowledge to knowledge processes. Sociol Rural 48:313-329

Buck D, Getz C, Guthman J (1997) From farm to table: the organic vegetable commodity chain of northern California. Sociol Rural 37:3-20

Burch D, Lawrence G (2005) Supermarket own brands, supply chains and the transformation of the agri-food system. Int J Sociol Agric Food 13:1-18

Burch D, Lawrence G (2009) Towards a third food regime: behind the transformation. Agric Hum Values 26:267-279

Burton RJF (2004) Seeing through the 'good farmer's' eyes: toward developing an understanding of the social symbolic value of 'productivist' behaviour. Sociol Rural 44:195-215

Burton RJF, Paragahawewa UH (2011) Creating culturally sustainable agri-environmental schemes. J Rural Stud 27:95-104

Burton RJF, Schwarz G (2013) Result-oriented agri-environmental schemes in Europe and their potential for promoting behavioural change. Land Use Policy 30:628-641
Burton RJF, Wilson GA (2006) Injecting social psychology theory into conceptualisations of agricultural agency: towards a postproductivist farmer self-identity? J Rural Stud 22:95-115

Burton RJF, Kuczera C, Schwarz G (2008) Exploring farmers' cultural resistance to voluntary agri-environmental schemes. Sociol Rural 48:16-37

Campbell H (2009) Breaking new ground in food regime theory: corporate environmentalism, ecological feedbacks and the 'food from somewhere' regime? Agric Hum Values 26:309-319

Campbell H, Burton R, Cooper M, Henry M, Le Heron E, Le Heron R, Lewis N, Pawson E, Perkins H, Roche M, Rosin C, White T (2009) Forum: from agricultural science to "biological economies"? N Z J Agric Res 52:91-97

Campbell H, Rosin C, Hunt L, Fairweather J (2012) The social practice of sustainable agriculture under audit discipline: initial insights from the ARGOS project in New Zealand. J Rural Stud 28:129-141

Carolan MS (2006) Do you see what I see? Examining the epistemic barriers to sustainable agriculture. Rural Sociol 71:232-260

Carolan MS (2011) Embodied food politics. Ashgate, Burlington, p 190

Carolan MS (2013) The wild side of agro-food studies: on co-experimentation, politics, change, and hope. Sociol Rural 53:413-431

Castree N (2003) Commodifying what nature? Prog Hum Geogr 27:273297

Castree N (2008a) Neoliberalising nature: processes, effects, and evaluations. Environ Plan A 40:153-173

Castree N (2008b) Neoliberalising nature: the logics of deregulation and reregulation. Environ Plan A 40:131-152

Clapp J, Fuchs D (2009) Agrifood corporations, global governance and sustainability: a framework analysis. In: Clapp J, Fuchs D (eds) Corporate power in global agrifood governance. The MIT Press, Cambridge, pp 1-25

Compagnone C (2014) Les viticulteurs bourguignons et le respect de l'environnement. Réseaux de dialogues professionnels et dynamiques de changement. Rev Fr Sociol 55:319-358

Compagnone C, Hellec F (2015) Farmers' professional dialogue networks and dynamics of change: the case of ICP and no-tillage adoption in burgundy (France). Rural Sociol 80:248-273

Crouch C (2011) The strange non-death of neoliberalism. Polity Press, Cambridge, $\mathrm{p} 224$

Curry N, Winter M (2000) European briefing: the transition to environmental agriculture in Europe: learning processes and knowledge networks. Eur Plan Stud 8:107-121

Davey SS, Richards C (2013) Supermarkets and private standards: unintended consequences of the audit ritual. Agric Hum Values 30:271281

Davidson-Hunt IJ (2006) Adaptive learning networks: developing resource management knowledge through social learning forums. Hum Ecol 34:593-614

de Sainte Marie C (2014) Rethinking agri-environmental schemes. A result-oriented approach to the management of species-rich grasslands in France. J Environ Plan Manag 57:704-719

de Snoo GR, Herzon I, Staats H, Burton RJF, Schindler S, van Dijk J, Lokhorst AM, Bullock JM, Lobley M, Wrbka T, Schwarz G, Musters CJM (2013) Toward effective nature conservation on farmland: making farmers matter. Conserv Lett 6:66-72

Deverre C, de Sainte-Marie C (2008) L'écologisation de la politique agricole européenne. Verdissement ou refondation des systèmes agro-alimentaires ? Rev Agric Environ Stud Revue d'Etudes en Agriculture et Environnement (RAEStud) 89:83-104

Dixon J (2007) Supermarkets as new food authorities. In: Burch D, Lawrence G (eds) Supermarkets and agri-food supply chains: transformations in the production and consumption of foods. Edward Elgar Publishing, Cheltenham, pp 29-50

Dolan C, Humphrey J (2000) Governance and trade in fresh vegetables: the impact of UK supermarkets on the African horticulture industry. J Dev Stud 37:147-176 
Droz Y (2001) Le paysan jurassien: un fonctionnaire qui s'ignore? Le mythe du libre entrepreneur et la réalité des subventions fédérales, J Anthropol 84:173-201

Droz Y, Forney J (2007) Un métier sans avenir? La Grande transformation de l'agriculture suisse romande. Karthala/IUED, Paris/Genève, p 198

Droz Y, Miéville-Ott V (2001) On achève bien les paysans. Reconstruire une identité paysanne dans un monde incertain. Georg, ChêneBourg/Genève, $\mathrm{p} 224$

Droz Y, Miéville-Ott V, Jacques-Jouvenot D, Lafleur G (2014) Malaise en agriculture. Une approche interdisciplinaire des politiques agricoles France-Québec-Suisse. Karthala, Paris, p 192

Emery SB, Franks JR (2012) The potential for collaborative agrienvironment schemes in England: can a well-designed collaborative approach address farmers' concerns with current schemes? J Rural Stud 28:218-231

Evans N, Morris C, Winter M (2002) Conceptualizing agriculture: a critique of post-productivism as the new orthodoxy. Prog Hum Geogr 26:313-332

FOAG (2015) Rapport agricole 2014. Federal Office for Agriculture, Bern, Switzerland, p 262

Forney J (2007) Ethos et subversions quotidiennes chez les paysans romands. In: Chappaz S, Monsutti A, Schinz O (eds). Entre ordre et subversion. Karthala/IUED, Paris/Genève, p 119-134

Forney J (2012) Eleveurs laitiers. Peuvent-ils survivre? Presse Polytechniques et Universitaires Romandes, Lausanne, p 126

Forney J (2016) Enacting Swiss cheese: about the multiple ontologies of local food. In: Le Heron R et al (ed). Biological economies: experimentation and the politics of agrifood frontiers. Routledge, part 1, $67-81$

Forney J, Häberli I (2016) Introducing 'Seeds of Change' into the Food System? Localisation Strategies in the Swiss Dairy Industry. Sociologia Ruralis 56:135-156

Foucault M (1994) Dits et Écrits II. tome 2: 1976-1988, Gallimard, Paris, p 1736

Franks JR, Emery SB (2013) Incentivising collaborative conservation: lessons from existing environmental stewardship scheme options. Land Use Policy 30:847-862

Franks JR, Mc Gloin A (2007) Environmental co-operatives as instruments for delivering across-farm environmental and rural policy objectives: lessons for the UK. J Rural Stud 23:472-489

Freidberg S (2007) Supermarkets and imperial knowledge. Cult Geogr $14: 321-342$

Friedmann H, McMichael P (1989) Agriculture and the State system: the rise and decline of national agricultures, 1870 to the present. Sociol Rural 29:93-117

Friedmann H, McNair A (2008) Whose rules rule? Contested projects to certify 'Local production for distant consumers'1. J Agrar Chang 8: 408-434

Fuchs D, Kalfagianni A, Havinga T (2011) Actors in private food governance: the legitimacy of retail standards and multistakeholder initiatives with civil society participation. Agric Hum Values 28:353-367

Gereffi G, Humphrey J, Sturgeon T (2005) The governance of global value chains. Rev Int Polit Econ 12:78-104

Germov J, Williams L (2008) A sociology of food and nutrition. The social appetite, 3rd ed. Oxford University Press, p 444

Gibbon P, Bair J, Ponte S (2008) Governing global value chains: an introduction. Econ Soc 37:315-338

Glasbergen P (2000) The environmental cooperative: self-governance in sustainable rural development. J Environ Dev 9:240-259

Goodman D, DuPuis EM (2002) Knowing food and growing food: beyond the production-consumption debate in the sociology of agriculture. Sociol Rural 42:5-22

Goodman D, Dupuis EM, Goodman M (2014) Alternative food networks: knowledge, practice, and politics. Routledge, London, p 320
Gorton M, Zarić V, Lowe P, Quarrie S (2011) Public and private agrienvironmental regulation in post-socialist economies: evidence from the Serbian fresh fruit and vegetable sector. J Rural Stud 27:144-152

Guthman J (2004) The trouble with 'Organic Lite' in California: a rejoinder to the 'Conventionalisation' debate. Sociol Rural 44:301-316

Guthman J (2007) The polanyian way? Voluntary food labels as neoliberal governance. Antipode 39:456-478

Guthman J (2008) Neoliberalism and the making of food politics in California. Geoforum 39:1171-1183

Hattersley L, Isaacs B, Burch D (2013) Supermarket power, own-labels, and manufacturer counterstrategies: international relations of cooperation and competition in the fruit canning industry. Agric Hum Values 30:225-233

Henson S (2011) Private agrifood governance: conclusions, observations and provocations. Agric Hum Values 28:443-451

Heynen N, Robbins P (2005) The neoliberalization of nature: governance, privatization, enclosure and valuation. Capital Nat Social $16: 5-8$

Higgins V, Dibden J, Cocklin C (2008) Building alternative agri-food networks: certification, embeddedness and agri-environmental governance. J Rural Stud 24:15-27

Hinrichs C (2010) Conceptualizing and creating sustainable food systems: how interdisciplinarity can help. In: Blay-Palmer A (ed) Imagining sustainable food systems. Theory and practice. Ashgate, Farnham, pp 17-35

Home R, Balmer O, Jahrl I, Stolze M, Pfiffner L (2014) Motivations for implementation of ecological compensation areas on Swiss lowland farms. J Rural Stud 34:26-36

Horlings LG, Marsden TK (2011) Towards the real green revolution? Exploring the conceptual dimensions of a new ecological modernisation of agriculture that could 'feed the world'. Glob Environ Chang 21:441-452

Ingram J (2008a) Agronomist-farmer knowledge encounters: an analysis of knowledge exchange in the context of best management practices in England. Agric Hum Values 25:405-418

Ingram J (2008b) Are farmers in England equipped to meet the knowledge challenge of sustainable soil management? An analysis of farmer and advisor views. J Environ Manag 86:214-228

Juntti M, Potter C (2002) Interpreting and reinterpreting agrienvironmental policy: communication, trust and knowledge in the implementation process. Sociol Rural 42:215-232

Kitchen L, Marsden T (2011) Constructing sustainable communities: a theoretical exploration of the bio-economy and eco-economy paradigms. Local Environ 16:753-769

Kloppenburg J (1991) Social theory and the de/reconstruction of agricultural science: local knowledge for an alternative agriculture 1. Rural Sociol 56:519-548

Kloppenburg J Jr, Hendrickson J, Stevenson GW (1996) Coming in to the foodshed. Agric Hum Values 13:33-42

Lamine C (2012) 'Changer de système': une analyse des transitions vers l'agriculture biologique à l'échelle des systèmes agri-alimentaires territoriaux. Terrains et Travaux 20:139-156

Lamine C (2015) Sustainability and resilience in agrifood systems: reconnecting agriculture, food and the environment. Sociol Rural $55: 41-61$

Lang T (2009) Reshaping the food system for ecological public health. J Hunger Environ Nutr 4:315-335

Lang T (2010) Crisis? What crisis? The normality of the current food crisis. J Agrar Chang 10:87-97

Lascoumes P, Le Galès P (2005) Introduction: L'action publique saisie par ses instruments. In: Lascoumes P, Le Galès P (eds) Gouverner par les instruments. Les presses de Sciences Po, Paris, pp 11-44

Lascoumes P, Le Galès P (2007) Introduction: understanding public policy through its instruments - from the nature of instruments to the sociology of public policy instrumentation. Governance 20:1-21 
Lawrence G, Campbell H (2014) Neoliberalism in the antipodes: understanding the influence and limits of the neoliberal political project. In: Wolf SA, Bonnano A (Eds). The neoliberal regime in the agrifood sector: crisis, resilience and restructuring. Routledge, UK, $p$ 263-283

Le Heron R (2003) Creating food futures: reflections on food governance issues in New Zealand's agri-food sector. J Rural Stud 19:111-125

Le Heron E, Le Heron R, Lewis N (2013) Wine economy as open assemblage: thinking beyond sector and region. N Z Geogr 69:221-234

Le Heron R, Campbell H, Lewis N, Carolan MS (2016) Biological economies: experimentation and the politics of agrifood frontiers. Routledge, UK, p 274

Lémery B (2003) Les agriculteurs dans la fabrique d'une nouvelle agriculture. Sociologie du Travail 45:9-25

Lémery B (2006) Nouvelle agriculture, nouvelles formes d'exercice et nouveaux enjeux du conseil aux agriculteurs. In: Rémy J, Brives $\mathrm{H}$, Lémery B (Eds). Conseiller en agriculture. Educagri/INRA, Dijon/ Paris, pp 236-252

Levkoe CZ (2011) Towards a transformative food politics. Local Environ 16:687-705

Lewis N, Le Heron R, Campbell H, Henry M, Le Heron E, Pawson E, Perkins H, Roche M, Rosin C (2013) Assembling biological economies: region-shaping initiatives in making and retaining value. $\mathrm{N} \mathrm{Z}$ Geogr 69:180-196

Lockie S, Higgins V (2007) Roll-out neoliberalism and hybrid practices of regulation in Australian agri-environmental governance. J Rural Stud 23:1-11

Lowe P (2010) Enacting rural sociology: or what are the creativity claims of the engaged sciences? Sociol Rural 50:311-330

Mann S (2003) Doing it the Swiss way. EuroChoices 2:32-35

Mansfield B (2004) Rules of privatization: contradictions in neoliberal regulation of north pacific fisheries. Ann Assoc Am Geogr 94:565584

Maris V (2014) Nature à vendre. Les limites des services écosystémiques. Quae, Paris

Marsden T (2000) Food matters and the matter of food: towards a new food governance? Sociol Rural 40:20-29

Marsden T (2010) Mobilizing the regional eco-economy: evolving webs of agri-food and rural development in the UK. Cambridge J Regions Econ Soc 3:225-244

Marsden T (2012) Towards a real sustainable agri-food security and food policy: beyond the ecological fallacies? The political quarterly 83 : 139-145

Marsden T (2013) From post-productionism to reflexive governance: contested transitions in securing more sustainable food futures. J Rural Stud 29:123-134

Mather AS, Hill G, Nijnik M (2006) Post-productivism and rural land use: cul de sac or challenge for theorization? J Rural Stud 22:441455

McGuire J, Morton L, Cast A (2013) Reconstructing the good farmer identity: shifts in farmer identities and farm management practices to improve water quality. Agric Hum Values 30:57-69

McKee A, Holstead K, Sutherland L-A, Pinto-Correia T, Guimarães H (2014) 'Shift happens': co-constructing transition pathways towards the regional sustainability of agriculture in Europe, 11th European IFSA Symposium,1-4 April 2014, Berlin, p 10

McMichael P (2000) The power of food. Agric Hum Values 17:21-33

McMichael P (2012) Biofuels and the financialization of the global food system. In: Rosin C, Stock P, Campbell H (eds) Food systems failure. The global food crisis and the future of agriculture. Earthscan, London, pp 60-82

Ménard C (2004) The economics of hybrid organizations. J Inst Theor Econ (JITE) Z Gesamte Staatswissenschaft 160:345-376

Mintz SW, Du Bois CM (2002) The anthropology of food and eating. Annu Rev Anthropol 31:99-119
Moberg M (2014) Certification and neoliberal governance: moral economies of fair trade in the eastern Caribbean. Am Anthropol 116:8 22

Mooney P (1988) My own boss? Class, rationality, and the family farm. Westview Press, Boulder, p 350

Morgan K, Sonnino R (2010) The urban foodscape: world cities and the new food equation. Cambridge J Regions Econ Soc 3:209-224

Moschitz H, Stolze M (2009) Organic farming policy networks in Europe: context, actors and variation. Food Policy 34:258-264

Muradian R, Corbera E, Pascual U, Kosoy N, May PH (2010) Reconciling theory and practice: an alternative conceptual framework for understanding payments for environmental services. Ecol Econ 69:1202-1208

Niska M, Vesala HT, Vesala KM (2012) Peasantry and entrepreneurship as frames for farming: reflections on farmers' values and agricultural policy discourses. Sociologia Ruralis 52:453-469

Norgaard RB (2010) Ecosystem services: from eye-opening metaphor to complexity blinder. Ecol Econ 69:1219-1227

OECD (2012) Water quality and agriculture: meeting the policy challenge, OECD studies on water. OECD publications p. 159

Olivier de Sardan J-P (2010) Développement, modes de gouvernance et normes pratiques (une approche socio-anthropologique). Can J Dev Stud Revue Canadienne d'études du Développement 31:5-20

Ong A (2006) Neoliberalism as exception: mutations in citizenship and sovereignty. Duke University Press, Durham, p 304

Ostrom E (2010) Beyond markets and states: polycentric governance of complex economic systems. Am Econ Rev 100:641-672

Potter C, Burney J (2002) Agricultural multifunctionality in the WTOlegitimate non-trade concern or disguised protectionism? J Rural Stud 18:35-47

Raynolds L, Murray D, Heller A (2007) Regulating sustainability in the coffee sector: a comparative analysis of third-party environmental and social certification initiatives. Agric Hum Values 24:147-163

Réviron S, Chappuis J-M (2005) Effects of the Swiss retailers' strategy on the governance structure of the fresh food products supply chains. Agribusiness 21:237-252

Richards C, Bjørkhaug H, Lawrence G, Hickman E (2013) Retailerdriven agricultural restructuring-Australia, the UK and Norway in comparison. Agric Hum Values 30:235-245

Rist S, Chidambaranathan M, Escobar C, Wiesmann U, Zimmermann A (2007) Moving from sustainable management to sustainable governance of natural resources: the role of social learning processes in rural India, Bolivia and Mali. J Rural Stud 23:23-37

Rosin C (2008) The conventions of agri-environmental practice in New Zealand: farmers, retail driven audit schemes and a new spirit of farming. GeoJournal 73:45-54

Rosin C, Campbell H (2009) Beyond bifurcation: examining the conventions of organic agriculture in New Zealand. J Rural Stud 25:35-47

Rosin C, Stock P, Campbell H (2011) Food system failure. The global food crisis and the future of agriculture. Earthscan, London, p 256

Salomon Cavin J (2013) Beyond prejudice: conservation in the city. A case study from Switzerland. Biol Conserv 166:84-89

Schäfer Elinder L, Joossens L, Raw M, Lang T (2003) Public health aspects of the EU common agricultural policy. Swedish National Institute of Public Health, p 108

Schneider F, Fry P, Ledermann T, Rist S (2009) Social learning processes in swiss soil protection - the 'From farmer-to farmer' project. Hum Ecol 37:475-489

Schneider F, Ledermann T, Fry P, Rist S (2010) Soil conservation in Swiss agriculture - approaching abstract and symbolic meanings in farmers' life-worlds. Land Use Policy 27:332-339

Scott S, Vandergeest P, Young M (2009) Certification standards and the governance of green foods in Southeast Asia. In: Clapp J, Fuchs D (eds) Corporate power in global agrifood governance. The MIT Press, Cambridge, pp 61-92 
Siebert R, Laschewski L, Dosch A (2008) Knowledge dynamics in valorising local nature. Sociol Rural 48:223-239

Sonnino R, Marsden T (2006) Beyond the divide: rethinking relationships between alternative and conventional food networks in Europe. J Econ Geogr 6:181-199

Sonnino R, Lozano Torres C, Schneider S (2014) Reflexive governance for food security: the example of school feeding in Brazil. J Rural Stud 36:1-12

Stock PV, Forney J (2014) Farmer autonomy and the farming self. J Rural Stud 36:160-171

Stock PV, Forney J, Emery SB, Wittman H (2014) Neoliberal natures on the farm: farmer autonomy and cooperation in comparative perspective. J Rural Stud 36:411-422

Stock PV, Carolan MS, Rosin C (2015) Food utopias. Reimagining citizenship, ethics and community, series in food, society and environment. Routledge, Abingdon, p 258

Sutherland L-A (2013) Can organic farmers be 'good farmers'? Adding the 'taste of necessity' to the conventionalization debate. Agric Hum Values 30:429-441

Tallontire A, Opondo M, Nelson V, Martin A (2011) Beyond the vertical? Using value chains and governance as a framework to analyse private standards initiatives in agri-food chains. Agric Hum Values 28: $427-441$

Tregear A (2011) Progressing knowledge in alternative and local food networks: critical reflections and a research agenda. J Rural Stud 27: 419-430

van der Ploeg JD (2008) The new peasantries. Struggles for autonomy and sustainability in an era of Empire and globalisation. Earthscan, London, $\mathrm{p} 356$

Van Hecken G, Bastiaensen J (2010) Payments for ecosystem services: justified or not? A political view. Environ Sci Pol 13:785-792

Vermeulen SJ, Campbell BM, Ingram JSI (2012) Climate change and food systems. Annu Rev Environ Resour 37:195-222
Walford N (2003) Productivism is allegedly dead, long live productivism. Evidence of continued productivist attitudes and decision-making in South-East England. J Rural Stud 19:491-502

Wallimann I (2015) Urban agriculture as embedded in the social and solidarity economy Basel: developing sustainable communities. In: Stock P, Rosin C, Carolan, M S (Eds). Food utopias: reimagining citizenship, ethics and community 79-87. Routledge, Milton Park, Abingdon, Oxon/New York

Ward P, Coveney J, Henderson J (2010) Editorial: a sociology of food and eating: why now? J Sociol 46:347-351

Wilson GA (2001) From productivism to post-productivism and back again? Exploring the unchanged natural and mental landscape of european agriculture. Trans Inst Br Geogr 26:77-102

Wilson GA (2007) Multifunctional agriculture. A transition theory perspective. CABI, Oxfordshire/Cambridge, p 368

Wilson GA, Hart K (2001) Farmer participation in agri-environmental schemes: towards conservation-oriented thinking? Sociol Rural 41: 254-274

Wiskerke JSC (2009) On places lost and places regained: reflections on the alternative food geography and sustainable regional development. Int Plan Stud 14:369-387

Wittman H, Beckie M, Hergesheimer C (2012) Linking local food systems and the social economy? Future roles for farmers' markets in Alberta and British Columbia. Rural sociology 77: 36-61

Wolf ER, Bonanno A (2014) The neoliberal regime in the agri-food sector: crisis, resilience and restructuring. Routledge, Abingdon, $p$ 308

Wynne-Jones S (2013) Ecosystem service delivery in wales: evaluating farmers' engagement and willingness to participate. J Environ Policy Plann 15:493-511 